\title{
KESIAPAN MAHASISWA TINGKAT AKHIR MENGHADAPI DUNIA KERJA DITINJAU DARI KONSEP DIRI DAN KOMPETENSI YANG DIMILIKI
}

\author{
Rachmawati, Wulan Murni Sulianti \\ Universitas Wisnuwardhana, Universitas Wisnuwardhana \\ rachma.widyantoro@gmail.com, wulanmurni@ymail.com
}

\begin{abstract}
ABSTRAK: Tuntutan di dunia industri berkembang pesat, yang juga menyebabkan kebutuhan untuk mendapatkan tenaga kerja yang memiliki kompetensi dan konsep diri yang tinggi sangat dibutuhkan. Banyaknya tenaga kerja yang tidak terserap dalam dunia industri merupakan tanda tanya, apakah memang adanya ketidaksiapan mahasiswa untuk bekerja karena konsep dirinya yang rendah, kompetensinya yang kurang mumpuni, ataukah karena kedua. Penelitian ini bertujuan untuk mengetahui pengaruh konsep diri dan kompetensi yang dimiliki terhadap kesiapan menghadapi dunia kerja pada mahasiswa tingkat akhir. Subyek dari penelitian ini adalah mahasiswa tingkat akhir Universitas Wisnuwardhana Malang, yang belum bekerja. Pengambilan sampel menggunakan teknik purposive random sampling. Pengolahan data menggunakan metode statistik analisa regresi dua jalur. Hasil uji analisa regresi dua faktor diperoleh $F_{\text {reg }}$ sebesar 9,961 $(p=0,000)$ menunjukkan hasil yang signifikan. Artinya ada pengaruh Konsep diri dan Kompetensi Mahasiswa tingkat akhir Universitas Wisnuwardhana Malang terhadap kesiapan dalam menghadapi dunia kerja. Hasil perhitungan $(r)=0,36$ menunjukkan hubungan dengan arah positif, yang artinya semakin tinggi konsep diri dan kompetensi mahasiswa maka semakin meningkat kesiapan mereka dalam menghadapi dunia kerja, sebaliknya semakin rendah konsep diri dan kompetensi mahasiswa maka semakin menurun kesiapan mereka dalam menghadapi dunia kerja. Hasil dari penelitian ini diharapkan dapat melakukan antisipasi dalam menyiapkan para mahasiswa agar siap bekerja setelah lulus nantinya.
\end{abstract}

Kata Kunci: Konsep Diri, Kompetensi, Kesiapan Kerja, Mahasiswa

ABSTRACT: The demand in the industrial is growing rapidly, which also leads to the need to get a workforce that has high competence and self-concept. There were number of workforces who are not absorbed in the industrial, because of their unreadiness's to work due to low self-concept, less competencies, or because of both of them. This research aims to determine the influence of self-concept and competence on the readiness to face the workplace for the final level students. The subject of this research is the final level students University of Wisnuwardhana Malang, which has not worked yet. Sampling using purposive random sampling technique. Data processing using statistical methods of regression analysis two factors. The result of regression analysis two factors obtained Freg equal to 9,961 ( $p=0,000)$ showed significant result. This means that there is an influence self concept and competence on readiness to face workplace of final level students University of Wisnuwardhana Malang. The calculation $(r)=0.36$ shows there 
is a positif relationship, which means that the higher self-concept and the students' competence, the more their readiness in facing the workplace, the lower the self-concept and the student's competence will decrease their readiness to face the workplace.

Key words: Self Concept; Competency; Readiness to Work; Undergraduate Student

\section{PENDAHULUAN}

Di era teknologi dan globalisasi, dunia industri dan organisasi menuntut tenaga kerjanya untuk memiliki kepribadian yang tangguh dan kemampuan yang tinggi untuk bekerja. Oleh karena itu penting bagi calon tenaga kerja untuk memiliki konsep diri dan kompetensi yang dibutuhkan oleh pemberi tenaga kerja. Namun, dewasa ini masih banyak dijumpai ketidaksiapan dari calon tenaga kerja menghadapi dunia kerja, dalam hal ini adalah mahasiswa tingkat akhir yang sedang mengerjakan skripsi, tetapi masih belum bekerja.

Calhoun dan Acocella (dalam Eliana, 2003) mengatakan bahwa konsep diri adalah gambaran mental diri sendiri yang terdiri dari pengetahuan tentang diri, penghargaan bagi diri sendiri dan penilaian terhadap diri sendiri. Sementara, Harry Stack Sullivan, seperti yang dikutip oleh Jalaludin (2005), menjelaskan jika kita diterima orang lain, dihormati, disenangi karena keadaan diri kita, kita akan cenderung bersikap menghormati dan menerima diri kita sebaliknya bila orang lain selalu meremehkan kita, menyalahkan kita dan menolak kita, kita akan cenderung tidak akan menyenangi diri kita.

Konsep diri yang dipunyai seseorang akan turut menentukan bagaimana ia menerima, merasakan dan merespon lingkungannya. Seseorang yang berpikir bahwa dirinya kurang baik maka ia menganggap remeh dirinya serta selalu membayangkan kegagalan disetiap usaha yang akan dilakukan, selanjutnya ia akan enggan untuk mencoba mengatasi kesulitan yang dihadapi. Tingkah laku tersebut menunjukkan keyakinannya bahwa orang tersebut tidak mempunyai kemampuan untuk melakukan suatu usaha dengan sebaik mungkin. Pandangan negative terhadap dirinya menyebabkan individu mengharapkan tingkat keberhasilan yang akan dicapai hanya pada taraf yang rendah. Sebaliknya seseorang yang menganggap dirinya positif perbuatan akan dilakukan sungguh-sungguh, ia akan mau mencoba mengatasi kesulitan yang dihadapi, dengan demikian akan bertambah kemungkinannya P-ISSN: 0853-8050 E-ISSN: 2502-6925 
PSIKOVIDYA

Vol 22, No. 2, Desember 2018

untuk sukses. Jadi seseorang yang masyarakat. Pada mahasiswa tingkat akhir mempunyai konsep diri yang tinggi akan yang memiliki konsep diri dan kompetensi menunjukkan tingkah laku yang berbeda dengan orang yang mempunyai konsep diri yang rendah.

Seema Sanghi (2007) mengatakan bahwa kompeten adalah keahlian dan standar performa yang dicapai oleh seseorang. Sementara itu kompetensi dikatakan sebagai perilaku yang diadopsi ketika menampilkan kompetennya (keahliannya). Menurut Spencer \& Spencer (1993), competency as 'an underlying characteristic of an individual that is casually related to criterion-referenced effecting and/or superior performance in a job situation'. Maksudnya adalah suatu karakteristik yang mendalam dan sebagai bagian dari kepribadian seseorang, yang perilakunya dapat diprediksi dalam situasi tugas yang diberikan.

Konsep diri memiliki peranan yang penting dalam menentukan kehidupan seseorang, karena akan menentukan dan mengarahkan tingkah laku individu terhadap kehidupannya di masa depan. Di mana seseorang yang memiliki konsep diri yang tinggi akan lebih meningkatkan kompetensi dirinya, yaitu meningkatkan pengetahuan dan ketrampilannya, sehingga ia pun akan siap dalam situasi apapun dalam menghadapi kehidupan di yang tinggi diharapkan akan membuat ia lebih siap dalam menghadapi persaingan dunia kerja. Sementara mahasiswa tingkat akhir yang memiliki konsep diri rendah dan kompetensi rendah, maka timbul rasa cemas dan kawatir ketika menghadapi persaingan dunia kerja, yang berakibat kegagalan dalam mencari pekerjaan yang sesuai dengan minat dan bidangnya.

Hasil studi awal dengan beberapa mahasiswa, diperoleh informasi bahwa mahasiswa di lingkungan Universitas Wisnuwardhana merasa tidak yakin dengan kemampuan yang dimilikinya dan merasa lebih rendah di bandingkan dengan mahasiswa dari universitas lainnya. Rasa pesimif pada akhirnya timbul, karena mereka merasa bahwa dapat diterima bekerja yang sesuai dengan bidang keilmuannya saja sudah merupakan prestasi yang besar. Hal ini dikarenakan tidak adanya keinginan untuk berjuang dan bersaing dengan lulusan dari universitas lainnya. Mereka merasa bahwa tidak memiliki kompetensi yang diinginkan oleh perusahaan-perusahaan besar berskala national.

Gambaran kondisi tersebut menarik minat peneliti untuk melakukan kajian lebih mendalam tentang pengaruh konsep 
diri dan kompetensi yang dimiliki terhadap kesiapan menghadapi dunia kerja pada mahasiswa tingkat akhir. Kondisi ketidaksiapan dari mahasiswa tingkat akhir karena konsep dirinya maupun tingkat kompetensi yang dimilikinya menyebabkan mereka seringkali menyerah dengan persaingan di era globalisasi ini, sehingga mereka lebih memilih untuk melamar di perusahaan lokal dan kecil walaupun sebenarnya tidak sesuai dengan minat mereka. Di harapkan ketika memang konsep diri dan kompetensi yang dimiliki memiliki pengaruh yang signifikan, maka akan didapatkan solusi yang tepat untuk mempersiapkan mahasiswa tingkat akhir dalam menghadapi dunia kerja dan bersaing secara sehat di era globalisasi ini.

\section{METODE PENELITIAN}

Penelitian ini merupakan penelitian kuantitatif, untuk melihat adanya pengaruh antara konsep diri dan kompetensi yang dimiliki mahasiswa tingkat akhir terhadap kesiapan mereka dalam menghadapi dunia kerja. Populasinya adalah mahasiswa tingkat akhir Universitas Wisnuwardhana Malang, yang belum bekerja. Teknik sampling yang digunakan adalah teknik purposive random sampling yaitu pengambilan dengan tujuan dan pertimbangan tertentu dan dilakukan secara acak (Sugiono, 2011). Sample dari penelitian ini sejumlah 131 mahasiswa tingkat akhir yang belum bekerja.

Pengumpulan data menggunakan questioner, dengan menyajikan tiga pengukuran skala, yaitu untuk mengukur tingkat konsep diri, kompetesi dan kesiapan kerja. Skala Konsep diri disusun berdasarkan indikator-indikator konsep diri, yaitu: rasa percaya diri (self confidence) dan harga diri (self esteem). Skala Kompetensi disusun berdasarkan indikator-indikator, yaitu pengetahuan yang dimiliki dan ketrampilan yang dimiliki. Skala kesiapan kerja diukur berdasarkan indikator-indikator, yaitu kecakapan dalam bidang akademis dan mental tanggung. Pengujian hipotesa dilakukan dengan menggunakan teknik analisa analisa regresi dua prediktor untuk menguji hubungan antara dua prediktor dengan variabel kriterium.

\section{HASIL DAN PEMBAHASAN}

Hasil uji analisa regresi dua faktor diperoleh $F_{\text {reg }}$ sebesar 9,961 $(p=0,000)$ menunjukkan hasil yang signifikan. Artinya ada pengaruh antara Konsep diri dan Kompetensi Mahasiswa tingkat akhir Universitas Wisnuwardhana Malang terhadap kesiapan dalam menghadapi dunia kerja. Hasil perhitungan $(\mathrm{r})=0,36 \quad(\mathrm{p}=0,000)$ menunjukkan hubungan yang signifikan dengan arah positif, yang artinya semakin 
tinggi konsep diri dan kompetensi mahasiswa maka semakin meningkat kesiapan mereka dalam menghadapi dunia kerja, sebaliknya semakin rendah konsep diri dan kompetensi mahasiswa maka semakin menurun kesiapan mereka dalam menghadapi dunia kerja.

Hasil perhitungan koefisien determinan (R2) diperoleh hasil $(0,135)$, artinya variabel konsep diri dan kompetensi mahasiswa hanya memberikan sumbangan terhadap kesiapan mereka dalam menghadapi dunia kerja 13,5\%, sedangkan sisanya $86,5 \%$ dipengaruhi oleh faktor lain. Hal ini menunjukkan adanya faktor lain yang juga cukup memberikan sumbangan besar pada kesiapan mahasiswa tingkat akhir dalam menghadapi dunia kerja, selain daripada konsep diri dan kompetensinya. Adanya faktor seperti nilai (values), kepercayaan (belief), pola asuh orangtua, suku bangsa, dukungan sosial dari teman maupun orang yang berarti, motivasi untuk merubah kehidupan menjadi lebih baik, dan sebagainya, diperkirakan dapat menjadi faktor-faktor yang juga dapat menyebabkan mahasiswa tingkat akhir tidak siap dalam menghadapi dunia kerja.

\section{KESIMPULAN SARAN}

Berdasarkan hasil penelitian dapat disimpulkan bahwa ada pengaruh yang cukup besar antara konsep diri dan kompetensi Mahasiswa tingkat akhir di Universitas Wisnuwardhana Malang terhadap kesiapan dalam menghadapi dunia kerja. Semakin tinggi konsep diri dan kompetensi mahasiswa maka semakin meningkat kesiapan mereka dalam menghadapi dunia kerja, sebaliknya semakin rendah konsep diri dan kompetensi mahasiswa maka semakin kurang kesiapan mereka dalam menghadapi dunia kerja.

Bagi mahasiswa merasa tidak yakin dengan kemampuan yang dimilikinya dan merasa lebih rendah di bandingkan dengan mahasiswa dari Universitas ternama lainnya, terutama Universitas Negeri, biasanya akan menumbuhkan rasa pesimis untuk dapat diterima dan bekerja di perusahaan besar, baik yang berskala nasional maupun internasional. Akibatnya daya juang mereka pun menjadi rendah untuk bersaing dengan di dunia Industri dalam skala yang lebih besar daripada lokal. Dibutuhkan dorongan dan dukungan terhadap mahasiswa agar mereka dapat meningkatkan konsep dirinya maupun kompetensi dirinya.

Pihak Universitas, yang dapat diwakili oleh Fakultas dapat mengarahkan para mahasiswa untuk mempersiapkan diri mereka sebelum di awal masuk kuliah, dengan mendorong mahasiswa untuk mengikuti kegiatan organisasi kemahasiswaan secara aktif. Pelatihan motivasi guna meningkatkan konsep dirinya dan mau meningkatkan kompetensinya. Fasilitas kegiatan unit kegiatan mahasiswa yang dibentuk sedemikian rupa untuk dapat memberikan bimbingan pada mereka dalam upaya meningkatkan kompetensi dan konsep dirinya. Memberikan peluang mahasiswa untuk magang di dunia Industri, diharapkan juga dapat meningkatkan kesiapan mereka dalam menghadapi dunia kerja dan mampu bersaing di era globalisasi ini. 


\section{DISKUSI}

Hasil penelitian menunjukkan bahwa adanya pengaruh yang signifikan antara konsep diri dan kompetensi yang dimiliki mahasiswa, sehingga membuat mahasiswa kurang memiliki kesiapan untuk memasuki dunia kerja, walaupun kontribusinya masih dikatakan kecil. Lingkungan Universitas Wisnuwardhana memiliki mahasiswa yang berasal dari berbagai suku bangsa di Indonesia, dengan berbagai macam budaya dan kebiasaan yang berbeda, yang bisa jadi menyebabkan adanya faktor lain yang memberikan kontribusinya terhadap kesiapan mahasiswa untuk memasuki dunika kerja.

Adanya harapan dari keluarga daerah asal mahasiswa, bahwa ketika mereka selesai kuliah akan kembali ke daerahnya, membuat mereka bisa jadi tidak memiliki keinginan untuk bersaing di perusahaan-perusahaan ternama di Indonesia. Merasa menjadi minoritas dapat pula menyebabkan mereka lebih memilih untuk kembali ke daerah asal dengan tujuan membangun sumber daya manusia di sana agar dapat lebih bersaing dengan daerah yang lain, terutama dengan orang-orang asal dari Jawa.

Adanya perbedaan budaya dan suku bangsa ini yang dapat diteliti lebih lanjut oleh peneliti setelahnya. Apakah memang faktor beragam budaya dan suku bangsa juga mempengaruhi kesiapan mahasiswa tingkat akhir untuk memasuki dunia kerja, bersaing dengan lulusan dari universitas lain di daerah
Jawa ini, terutama untuk dapat bekerja di perusahaan-perusahaan ternama, berskala nasional maupun internasional.

Hal lain yang memungkinkan menjadi faktor lain yang mempengaruhi kesiapan mahasiswa adalah keinginan mereka untuk membuka peluang usaha sendiri maupun masuk dalam usaha keluarga yang telah ada. Hal ini yang membuat mereka tidak terlalu memikirkan tingkat persaingan dan peluang untuk bekerja di perusahaan berskala nasional maupun internasional.

Wawasan mahasiswa tingkat akhir yang kurang luas terhadap dunia industri memungkinkan juga membuat mahasiswa kurang memiliki kesiapan untuk memasuki dunia kerja dengan tingkat kompetitif yang tinggi. Di mana mereka harus keluar dari zona nyamannya, hijrah ke kota besar atau kota industri untuk bersaing dengan lulusan universitas lain, membuat mereka enggan untuk lebih terbuka terhadap peluang yang besar. Mereka lebih menerima kondisi yang ada, karena bagaimana pun ketika mereka selesai kuliah sudah mendapatkan penghargaan yang cukup besar juga dari keluarga ataupun masyarakat yang ada di daerah asal mereka.

\section{DAFTAR PUSTAKA}

Burns, R.B. 1993. Konsep Diri, Teori, pengukuran dan perilaku. Jakarta: Arcan.

Dafidoff, L.L. 1988. Psikologi Suatu Pengantar. Jakarta: Erlangga.

Eliana, R. (2003). Konsep Diri Pensiuan. Jurnal. Di unduh dari

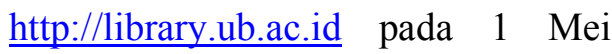
2016 
Gunarsa, S. D. dan Gunarsa, Ny. S. D. 1983. Psikologi Perkembangan Anak dan Remaja. Jakarta: PT. Gunung Mulia.

Murdoko, E., \& Widijo, H. 2004. Explore Your Personality-Plus. Jakarta: PT Eles Media Komputindo

Pujijogyanti, Clara R. 1991. Konsep Diri Dalam Pendidikan. Jakarta: Penerbit Arcan.

Timpe, A.D. 1999. Seri Manajemen Sumber Daya Manusia, Mengelola Waktu. Terjemahan Susanto Boedidharmo. Jakarta: PT Elex Media Komputindo, Kelompok Gramedia

Rakhmat, Jalaluddin. 2005. Psikologi Komunikasi. Bandung: PT. Remaja Rosdakarya.

Sanghi, Seema. 2007. The Handbook of Competency Mapping:

Understanding, Designing and Implementing Competency Models in Organizations. Singapore: Sage publications Asia-Pacific Pte Ltd.

Spencer, Spencer. 1985. Competence at Work, Models for Superior Performance. Canada: John Wiley $\&$ Sons, Inc.

Sugiono, 2011. Metode Penelitian Kuantitatif, Kualitatif dan R\&D. Bandung: Alfabeta.

Weaver, R.L. 1993. Understanding Interpersonal Communication $6^{\text {th }}$ ed. New York: Harpercollins Coollege Publisher

Winarsunu, T. 2007. Statistik dalam Penelitian Psikologi dan Pendidikan. Malang: UPT Penerbitan Universitas Muhammadiyah Malang 